\title{
Interactive Learning: The Use of Multimedia with Hybrid Models in Balinese Language Subjects for Grade VII Students
}

\author{
I Gede Ardi Suryadharma ${ }^{1 *}$, I Nyoman Jampel ${ }^{2}$, I Komang Sudarma ${ }^{3}$ iD \\ 1,2,3 Universitas Pendidikan Ganesha, Singaraja, Indonesia \\ *Corresponding author: igdardi27@gmail.com
}

\begin{abstract}
Abstrak
Masih banyak guru yang kesulitan dalam menggunakan teknologi mengembangkan bahan ajar yang dapat memfasilitasi siswa dalam belajar. Hal ini berdampak pada hasil belajar siswa yang rendah. Tujuan penelitian ini yaitu menciptakan Emodul dengan model pembelajaran problem-based learning. Jenis penelitian ini yaitu pengembangan dengan menggunakan model ADDIE. Subjek uji ahli terdiri dari 3 orang yaitu 1 ahli mata pelajaran, 1 ahli desain pembelajaran, dan 1 ahli media pembelajaran. Subjek uji coba produk terdiri dari 9 siswa. Metode yang digunakan dalam mengumpulkan data yaitu observasi, wawancara, dan kuesioner. Instrument yang digunakan dalam mengumpulkan data yaitu kuesioner. Teknik yang digunakan untuk menganalisis data yaitu analisis deskriptif kualitatif dan kuantitatif. Hasil penelitian yaitu Penilaian yang diberikan oleh ahli isi pelajaran yaitu 96,47 (sangat baik). Penilaian dari ahli desain pembelajaran yaitu 93,33\% (sangat baik). Penilaian dari ahli media pembelajaran yaitu 97,5\% (sangat baik). Hasil uji coba perorangan, yaitu 95,53\% (sangat baik), dan hasil uji coba kelompok kecil yaitu 95,53\% (sangat baik). Dapat disimpulkan bahwa E-modul dengan model pembelajaran problem-based learning valid dan layak diterapkan dalam proses pembelajaran. Implikasi penelitian ini yaitu E-modul dengan model PBL dapat digunakan guru dalam pembelajaran.
\end{abstract}

Kata kunci: Multimedia Interaktif, Hybrid Learning, Bahasa Bali.

\begin{abstract}
The cultural shift in the era of globalization has greatly influenced the Balinese culture which is deeply ingrained for the Balinese. Therefore, innovative learning media is needed as an effort to prevent this cultural shift. This study aims to develop an interactive multimedia hybrid learning model in Balinese language subjects for seventh-grade junior high school students. Interactive learning multimedia developed using the Articulate Storyline 3 application because this application has features that are easy to use. This interactive multimedia development uses the ADDIE development model which consists of the analysis, design, development, implementation, and evaluation stages. The results of the validity of interactive multimedia development will be presented in five main points which include: subject matter experts, learning design experts, learning media experts, individual trials, and small group trials. The subjects of this study included experts, namely 1 subject matter expert, 1 learning design expert, 1 learning media expert, 3 individual test subjects, and 9 small group trial subjects. The methods used in collecting data are observation methods, interview methods, and questionnaire methods. The data analysis technique in this research is descriptive qualitative and descriptive quantitative. The data collection instrument in this study was using a questionnaire. The results of the calculation of the value of the experts (subject experts, instructional design, instructional media), individual trials, and small group trials get very good qualifications. Based on these qualifications, it can be concluded that the interactive multimedia hybrid learning model in Balinese class VII subjects is feasible to be applied to support the learning process.
\end{abstract}

Keywords: Interactive Multimedia, Hybrid Learning, Balinese Learning

$\begin{array}{ll}\text { History: } & \text { Publisher: Undiksha Press } \\ \text { Received : August 19, } 2021 & \text { Licensed: This work is licensed under } \\ \text { Revised : August 20, } 2021 & \text { a Creative Commons Attribution 3.0 License } \\ \text { Accepted : October 04, } 2021 & \text { CC () (O) } \\ \text { Published : October 25, } 2021 & \text { SA }\end{array}$

\section{INTRODUCTION}

The Covid-19 pandemic that has hit the world, including Indonesia, has had an impact on various aspects of human life, one of which is the education aspect (Abbasi et al., 2020; Yuzulia, 2021). As an effort to prevent the spread of the virus, the government announced a policy to maintain social distance, and all forms of activity were carried out at home including teaching and learning activities (Megawanti et al., 2020; Prawiyogi et al., 2020). Following the decision of the Minister of Education and Culture of the Republic of Indonesia regarding Circular Letter Number 4 of 2020 concerning the Implementation of Education Policies in the Emergency Period for the Spread of Covid-19 (Susilo et al., 2020). 
This requires educators to take the initiative to design the learning process by utilizing online media (online). The use of online media is carried out to ensure that learning activities take place even though there are no face-to-face sessions. Technology that supports learning activities utilizes online media including the internet, smartphones, and laptops/PC (Astuti \& Prestiadi, 2020). An extraordinary change occurred in the learning process during the Covid19 pandemic. All levels of education seem to be forced to transform to adapt suddenly to learning activities from home through online media. This is certainly felt heavy by educators and students because it is not fully ready and is not an easy problem if it has to be implemented soon. Positive, creative, and innovative thinking can help overcome various problems in the distance learning process during the Covid-19 pandemic by applying fun online learning media, to produce quality learning outcomes with the hope that students can participate in the learning process optimally (Wuarlela, 2020; Yuzulia, 2021).

The cultural shift in the era of globalization is very influential on Balinese culture which is entrenched for Balinese people, including the existence of the use of the Balinese language which is experiencing a dynamic (Suwardani, 2015). The extinction of a language can have a very fatal impact, especially when viewed from the point of view of cultural loss (Arissusila, 2021). Language and culture are two things that are closely related and cannot be separated. Conservation efforts need to be considered immediately for the sake of the existence of the Balinese language itself. Schools as educational institutions can be a means of preserving the Balinese language from an early age through Balinese language subjects (Arissusila, 2021; Suweta, 2020). However, since the Covid-19 pandemic broke out, the government implemented a learning process carried out from home. This has an impact on the learning process, especially in Balinese language subjects which emphasize direct interaction. In the 2013 Curriculum, Balinese language subjects are included in local content, so the study schedule is only carried out once a week (Suweta, 2020). With relatively new learning conditions, the ability of educators to manage the learning process using technology will be tested. Inevitably, educators must begin to adapt to technological developments and the development of millennial generation skills. Therefore, educators need innovative learning strategies and media to create productive, innovative, and fun learning situations and conditions for students so that they can increase students' interest in learning even though the learning process is carried out online (Handarini \& Wulandari, 2020; Malyana, 2020).

Based on the results of observations and interviews conducted at the Undiksha Singaraja Laboratory Junior High School on March 26, 2021, information was obtained that teachers are very difficult to carry out online learning activities because there are no innovative and creative learning media to support the learning process, it is difficult to control student activities. When carrying out online learning activities, and the low participation and interest of students in participating in Balinese language learning. The average value of grade VII student learning outcomes in Balinese language subjects with a total of 19 students is relatively low seen from the average daily assessment and the average end-of-semester assessment result (HPAS) for the 2020/2021 academic year with minimum completeness criteria (KKM). ) which was set at 70 . Based on these data, it can be concluded that 11 out of 19 students have not completed taking Balinese language subjects in that semester with a reference value of KKM 70. An alternative solution is needed to overcome these problems. One solution that can be done is by implementing innovative and fun learning such as using IT media with good learning strategies that can help students learn so that the learning process becomes more productive, effective, and efficient during the Covid19 pandemic. One of the learning tools or facilities that can help students in learning activities during the COVID-19 pandemic is by using interactive multimedia learning (Dwiqi et al., 2020; Hakim \& Windayana, 2016a). Interactive learning multimedia is media that contains text, graphics, sound, photos, moving images, still images, and animations (Harjono 
et al., 2015). Interactive learning multimedia is very useful for students to improve their skills and effectiveness in learning Balinese language subjects either independently or online. The use of interactive learning multimedia in the learning process is expected to support a more effective and efficient learning process following predetermined learning objectives. The advantages of using interactive learning multimedia in the learning process where learning materials can be packaged concretely supported by visuals and audio according to the knowledge illustration that will be given to students (Hakim \& Windayana, 2016b; Sahronih et al., 2019).

Interactive learning multimedia is one of the media that can be applied to Balinese language subjects to deliver learning materials very effectively and efficiently. Interactive multimedia is a program used to deliver learning that contains digital content with integrated combinations of audio, text, image, video, and animation (Loris, 2017; Parvin \& Salam, 2018). In line with that, the use of interactive multimedia learning in the learning process can increase efficiency, increase motivation, facilitate active and experimental learning, studentcentered learning, and guide students to learn better (Rahmadianto \& Melany, 2018). Interactive learning multimedia can be packaged systematically to make it easier for students to learn the material available in the learning media (Widyatmojo \& Muhtadi, 2017). The use of interactive multimedia learning without the help of the right learning model will certainly not get maximum results, because it only attracts students' attention (Nopriyanti \& Sudira, 2015). So that the use of interactive learning multimedia in the learning process must be supported by learning models that are in accordance with the conditions of learning carried out online as a result of the covid-19 pandemic (Purwanti \& Krisnadi, 2020). One of the learning models that can support the use of interactive multimedia in the learning process is the hybrid learning model.

Hybrid learning is a learning method that combines two or more methods and approaches in learning to achieve the objectives of the learning process (Rahardjanto et al., 2019). The results of previous studies stated that the application of a hybrid learning model improves the quality of learning in students (O'Byrne \& Pytash, 2015; Saichaie, 2020). Another form of hybrid learning is virtual meetings between educators and students (Li et al., 2021). Where they are possible to be in different places but can give each other feedback, ask questions, answer, interact between students and educators as well as between students (O'Byrne \& Pytash, 2015; Saichaie, 2020). The use of interactive multimedia learning by applying a hybrid learning model makes the teacher in addition to acting as a teacher, he can also be a mentor for students to learn independently assisted by interactive multimedia learning (O’Byrne \& Pytash, 2015; Shen \& Ho, 2020). This study aims to develop an interactive multimedia hybrid learning model in Balinese language subjects for seventh-grade junior high school students. Interactive learning multimedia developed using the Articulate Storyline 3 application because this application has features that are easy to use. The development of interactive multimedia is expected that students will be more interested in learning the subject matter of Balinese language subjects because students can learn practically anywhere and anytime.

\section{METHODS}

This study aims to create interesting interactive teaching materials used in the learning process. Interactive multimedia was developed using simple software, namely Articulate Storyline 3 and also using other applications such as Adobe Photoshop, Adobe Illustrator, Filmora, Adobe Premiere, and Audacity. So the final result that is expected in this interactive multimedia is in the form of interactive teaching materials that can be used anywhere. In the research and development of interactive multimedia learning media, the 
ADDIE development model reference (Analysis, Design, Development, Implementation, and Evaluation) is used. This model was chosen because it is simple and has systematic, easy, and clear stages of development. This development model also provides flexibility to evaluate and revise at each stage that is passed. The stages of the ADDIE development model are (1) Analysis, at this stage, a thorough analysis is carried out related to learning activities and facilities. (2) Design (design) at this stage the activities carried out are making flowcharts, systematic preparation of material presentation, visualization, and designing evaluation tools. (3) Development, at this stage the development of products that have been previously designed in accordance with the situation analysis carried out in the first stage is carried out. (4) Implementation, at this stage the product that has been developed is implemented in the field in order to see the effectiveness of its use. (5) Evaluation at this stage the activities carried out are evaluating the products that have been developed. Evaluation is carried out to improve the products that have been developed (Sugiyono, 2014; Tegeh \& Jampel, 2017).

The development of interactive multimedia uses the ADDIE development method. The stages of development carried out are (1) the analysis stage, conducting a thorough analysis related to learning activities and facilities. (2) In The design stage, the activities carried out are making flowcharts, preparing the systematic presentation of material, visualization, and designing evaluation tools. (3) In The development stage, the activities carried out are developing interactive multimedia and other learning media needed in this interactive multimedia such as learning videos. The development stages are (a) interface development, (b) hybrid learning design (c) Asset Collecting (Asset Collection in the form of image, audio, and video assets). (4) Work, after all the components needed in making interactive multimedia have been obtained, it will enter the working phase. Initial work is done by determining the design that will be used in each page of interactive multimedia. The whole process is carried out in unifying the design and material using Articulate Storyline 3. This interactive multimedia development also uses other design applications such as Adobe Illustrator, Adobe Premiere, Adobe Photoshop, Filmora, and Audacity. The composition of the interactive multimedia framework that will be developed is the main page containing the competency menu, material menu, developer profile menu, and evaluation menu. In the material menu, there are other teaching materials, namely learning videos, which will help students understand the learning material. (5) Implementation stage, after the product is developed and feasible, the next stage is to implement it for individual test subjects and small group test subjects. The assessment aims to assess the feasibility of the product that has been developed. (6) Evaluation stage, the activities carried out are the evaluation of interactive multimedia product development. Evaluation is carried out to determine the validity or feasibility of interactive multimedia products that have been developed.

The product developed in this research development is in the form of interactive multimedia. To obtain a valid product, a trial phase is needed to determine its validity. The trial design was carried out in two stages, namely: (1) Expert review, interactive multimedia that had been developed was reviewed by three experts consisting of, (a) learning content experts, (b) learning design experts, and (c) learning design experts. Instructional Media. (2) Product trials, product developments that have been validated by experts, are followed by conducting trials for students. The trial was carried out in two stages, namely, (a) individual trials, (b) and small group trials. The subjects of this study were seventh-grade students at the Undiksha Laboratory Junior High School, Singaraja. Types of data collected in this study include quantitative data, quantitative data is a type of data that can be measured (measurable) or calculated directly as a variable number or number. In this study, the methods used in collecting data are the observation method, the interview method, and the questionnaire method. In this study, the instruments used in collecting data were: observation sheets, interview sheets, and questionnaire sheets. The observation sheet is used to determine 
the learning facilities owned by the school and students, as well as to see the learning process that occurs in the classroom. Data analysis of data starting from the beginning of data collection is carried out intensively, namely at the reflection stage of each learning activity. The data analysis process begins by examining all existing data from various stages of learning. The stages of data analysis activities are (1) qualitative descriptive analysis, (2) quantitative descriptive analysis, (3) data reduction, (4) data presentation, and (5) concluding.

\section{RESULTS AND DISCUSSION}

\section{Results}

In this interactive multimedia development, the researcher uses the ADDIE development model. This development model has five stages, namely: (1) analysis, (2) design, (3) development, (4) implementation, and (5) evaluation. The first step is an analysis which includes the identification of learning activities and learning facilities. The results of the analysis of learning activities through observation found that some students feel bored quickly in learning, this is due to the lack of interactive learning media that can motivate students in learning. The results of the analysis of learning facilities found that learning facilities such as computer labs, LCD, and internet access that can support the learning process. The results of interviews conducted with class VII students showed that all students were able to operate computers and laptops well. Based on this, it can be concluded that interesting teaching materials are needed so that they can support students in independent learning such as interactive multimedia. In interactive multimedia, there are text, images, audio, video, and animation that can support the learning process. Interactive multimedia can be accessed via laptops or computers that can support learning, especially in Balinese class VII subjects.

The second step is the design stage, the activities carried out at this stage are, (1) making flowcharts and interactive multimedia storyboards, (2) creating an interactive multimedia framework, (3) determining the design of interactive multimedia displays, (4) compiling Interactive Multimedia Assessment Instruments, and (5) compiling RPP (Learning Implementation Plan). The third step is the development stage, the activities carried out at this stage are, (1) developing interactive multimedia content, (2) developing interactive multimedia using the Articulate Storyline 3 application, and (3) developing evaluations to determine student understanding after studying the material contained in the program. on interactive multimedia. The fourth step is the implementation stage, the activities carried out at this stage are implementing the products that have been developed, namely interactive multimedia. Before implementation, the product will be tested for validity by subject content experts, learning design experts, and learning media experts. After the product validation test was completed by the experts, it was followed by individual trials and small group trials. The fifth step is the evaluation stage, the activities carried out at this stage are formative evaluation. Formative evaluation is carried out to assess the products that have been developed.

The results of the validity of the Interactive Multimedia Hybrid Learning Model in Balinese language subjects will be presented according to (1) learning content experts, (2) learning design experts, (3) learning media experts, (4) individual trials, and (5) group trials. small. The results of the validity of the Interactive Multimedia Hybrid Learning Model in Balinese language subjects are known by using the questionnaire method as shown in Table 1In this interactive multimedia development, the researcher uses the ADDIE development model. This development model has five stages, namely: (1) analysis, (2) design, (3) development, (4) implementation, and (5) evaluation. The first step is an analysis which includes the identification of learning activities and learning facilities. The results of the 
analysis of learning activities through observation found that some students feel bored quickly in learning, this is due to the lack of interactive learning media that can motivate students in learning. The results of the analysis of learning facilities found that learning facilities such as computer labs, LCD, and internet access that can support the learning process. The results of interviews conducted with class VII students showed that all students were able to operate computers and laptops well. Based on this, it can be concluded that interesting teaching materials are needed so that they can support students in independent learning such as interactive multimedia. In interactive multimedia, there are text, images, audio, video, and animation that can support the learning process. Interactive multimedia can be accessed via laptops or computers that can support learning, especially in Balinese class VII subjects.

The second step is the design stage, the activities carried out at this stage are, (1) making flowcharts and interactive multimedia storyboards, (2) creating an interactive multimedia framework, (3) determining the design of interactive multimedia displays, (4) compiling Interactive Multimedia Assessment Instruments, and (5) compiling RPP (Learning Implementation Plan). The third step is the development stage, the activities carried out at this stage are, (1) developing interactive multimedia content, (2) developing interactive multimedia using the Articulate Storyline 3 application, and (3) developing evaluations to determine student understanding after studying the material contained in the program. The fourth step is the implementation stage, the activities carried out at this stage are implementing the products that have been developed, namely interactive multimedia. Before implementation, the product will be tested for validity by subject content experts, learning design experts, and learning media experts. After the product validation test was completed by the experts, it was followed by individual trials and small group trials. The fifth step is the evaluation stage, the activities carried out at this stage are formative evaluation. Formative evaluation is carried out to assess the products that have been developed. The results of the validity of the Interactive Multimedia Hybrid Learning Model in Balinese language subjects will be presented according to (1) learning content experts, (2) learning design experts, (3) learning media experts, (4) individual trials, and (5) small group trials. The results of the validity of the Interactive Multimedia Hybrid Learning Model in Balinese language subjects are known by using the questionnaire method as shown in Table 1.

Table 1. Percentage of Validity Results of Hybrid Learning Modeh Interactive Multimedia Development

\begin{tabular}{clcc}
\hline No & \multicolumn{1}{c}{ Trial Subject } & Validity Results & Description \\
\hline $\mathbf{( 1 )}$ & \multicolumn{1}{c}{$(2)$} & $(3)$ & $(4)$ \\
\hline $\mathbf{1}$ & Learning Content Expert Test & $94,16 \%$ & Very good \\
$\mathbf{2}$ & Learning Design Expert Test & $94,66 \%$ & Very good \\
$\mathbf{3}$ & Learning Media Expert Test & $93,63 \%$ & Very good \\
$\mathbf{4}$ & Individual Trial & $96,66 \%$ & Very good \\
$\mathbf{5}$ & Small Group Trial & $93,14 \%$ & Very good \\
\hline
\end{tabular}

\section{Discussion}

Based on the results of reviews from learning content experts, the results of the calculation of the value are $94.16 \%$ so that they are in very good qualifications. Very good qualifications can be achieved due to several things, namely (1) the clarity of the mapping of basic competencies, indicators, and learning objectives contained in interactive multimedia, (2) systematic suitability, material content, and depth of material presented in interactive multimedia, (3) on the language aspect of the clarity of information can be conveyed well, the use of language and the legibility of the text is clear, and (4) the clarity of the formulation of 
the evaluation questions, and the level of difficulty of the questions are appropriate. This is in line with research that states that the clarity of indicators and learning objectives will improve the quality of better learning (Andriawan \& Suparman, 2015; Jannah \& Wiyatmo, 2018). A coherent presentation of the material will be interesting and easier for students to understand (Faisal \& Sulkipani, 2016; Saidah \& Damariswara, 2019). This can be proven from the results of the assessment of learning content experts on instrument items related to the suitability of learning indicators with the material in interactive multimedia obtaining a percentage $(100 \%)$ with very good criteria and on instrument items related to presenting material in a coherent manner obtaining a percentage (100\%) with criteria very good. Based on the results of the assessment that has been given by subject content experts using a 5 scale assessment, there are eight of the twelve questionnaire items that get a value of 5 and four of the twelve questionnaire items to get a value of 4 . Based on this assessment it can be said that the content aspect of interactive multimedia which has been developed is suitable for use by students in learning Balinese language subjects.

Based on the results of a review from learning design experts, the results of the calculation of the value are $94.66 \%$, the score is in very good qualification. Very good qualifications can be achieved due to several things, namely (1) clarity of subject identity and conformity of indicators with basic competencies, (2) clarity of systematic presentation of material so that it is easy to understand, (3) compatibility of storyboards with interactive multimedia, and (4) clarity of instructions in question work. This is in line with research that states that the use of learning media in the learning process can increase students' interest, interest, and activeness in participating in learning, and is effective for improving student learning outcomes (Lukman et al., 2019; Yusantika et al., 2018). The use of learning media in learning activities must be able to generate new desires and interests, generate motivation, stimulate learning, help facilitate the learning process, and bring a positive psychological influence on students (Amalia \& Brata, 2018; Triana \& Retnosary, 2020). This can be proven from the results of the assessment by learning design experts on instrument items related to presenting material in an innovative way that can increase target interest in obtaining a percentage $(100 \%)$ with very good criteria, and on instrument items related to the clarity of material descriptions obtaining a percentage (100\%) with criteria very good, as well as on the items of the instrument, the clarity of the instructions for the evaluation process obtained a percentage $(100 \%)$ with very good criteria. Based on the results of the assessment that has been given by the learning design expert who uses a 5-scale assessment, there are eight out of fifteen questionnaire items getting a value of 5, and seven of the fifteen questionnaire items getting a value of 4 . Based on this assessment it can be said that aspects of learning design in interactive multimedia which has been developed is suitable for use by students in learning Balinese language subjects.

Based on the results of a review from learning media experts, the results of the calculation of the value are $93.63 \%$ where the score is in very good qualification. Very good qualifications can be achieved due to several things, namely (1) the suitability of the use of elements such as images, text, video, audio, and animation in delivering messages that can support understanding of the material, (2) clarity of title, goals, and developer identity, and (3) presentation consistency. The suitability and readability of the right text will be accepted by the sense of sight so that the message can be conveyed properly to students (Kharisma \& Arvianto, 2019; Patandung, 2017). Submission of learning materials through the use of multimedia in which there are elements such as text, images, sound, video, and animation in accordance with effective materials to clarify the material presented and can increase student interest and motivation in the learning process. This can be proven by the results of the assessment of the learning media experts regarding the items of the suitability of the text type and the readability of the text obtaining a percentage (100\%) with very good criteria, on the 
items of the image, video, audio, and animation resolution quality instruments obtaining a percentage $(100 \%)$ with very good criteria, as well as on the consistency of the material presentation instrument items get a percentage (100\%) with very good criteria. Based on the results of the assessment that has been given by learning media experts using a 5 -scale assessment, there are fifteen out of twenty-two questionnaire items getting a value of 5 , and seven of the twenty-two questionnaire items getting a value of 4 . Based on this assessment it can be said that the media aspect in interactive multimedia that has been developed is suitable for use by students in learning Balinese language subjects.

Based on the results of the assessment of the individual trials obtained an achievement rate of $96.66 \%$, where the score is in very good qualification. The results of the assessment of the small group trial obtained an achievement rate of $93.14 \%$, where the score was in very good qualification. The interactive multimedia that has been developed gets very good qualifications due to several things, namely (1) the ease of use of interactive multimedia, (2) the use of media to facilitate the learning process, and (3) the questions presented on the media are in accordance with the material provided. This is in line with the opinion which states that the appearance of attractive learning media can motivate students in learning, and communicative language can make it easier for students to understand learning materials (Banindro, 2019; Suryana, 2017). This can be proven from the results of student assessments in individual and small group trials of instrument items related to the application of Emodules that can motivate students in learning to get a percentage $(100 \%)$ with very good criteria, and very good criteria $(96.66 \%)$ in small group trials, as well as on instrument items related to the use of interactive multimedia to facilitate the learning process in obtaining a percentage $(100 \%)$ with very good criteria in individual trials and obtaining a percentage $(100 \%)$ with very good criteria in small group trials.

The implications of this interactive multimedia development research are as follows. (1) This development research has an impact on teachers to carry out reforms in the learning process such as the use of interactive multimedia in classroom learning activities so that it is not monotonous to use the lecture learning method. (2) This development research has an impact on increasing students' interest and interest in learning by using the Interactive Multimedia Hybrid Learning Model. (3) This development research encourages teachers to take advantage of the facilities and infrastructure available in schools that have been underutilized so far. (4) Students will have skills in using technology, so that they can support student learning activities.

\section{CONCLUSION}

The conclusions in this study include two main things which include: (1) the process of developing interactive multimedia hybrid learning models, (2) the validity of interactive multimedia hybrid learning models according to the results of expert evaluations, individual and small group trials. The description will be presented as follows. (1) The interactive multimedia development process of this hybrid learning model has been developed through several stages. The interactive multimedia development stages of this hybrid learning model refer to the ADDIE development model, which consists of five stages, namely: 1) analysis stage, 2) design stage, 3) development stage, 4) implementation stage (implementation), and 5) evaluation stage. (2) The validity of the interactive multimedia hybrid learning model that has been developed is measured through (1) the results of reviews from learning content experts with very good qualifications $(94.16 \%)$, (2) the results of reviews from learning design experts with very good qualifications $(94,66 \%)$, the results of reviews from learning media experts with very good qualifications (93.63\%), individual trials with very good qualifications $(96.66 \%)$, and small group trials with very good qualifications $(93.14 \%)$. 
Based on the results of the assessment, it can be concluded that the interactive multimedia hybrid learning model is feasible to be applied to class VII students of Balinese language subjects.

\section{REFERENCES}

Abbasi, S., Ayoob, T., Malik, A., \& Memon, S. I. (2020). Perceptions of students regarding e-learning during covid-19 at a private medical college. Pakistan Journal of Medical Sciences, 36(COVID19-S4), S57-S61. https://doi.org/10.12669/pjms.36.COVID19S4.2766.

Amalia, F., \& Brata, A. H. (2018). Analisis Tingkat Penerimaan Sistem E-Learning menggunakan Blog Gratis sebagai Alternatif Media Pembelajaran pada Guru. Jurnal Teknologi Informasi Dan Ilmu Komputer, 5(3), 335. https://doi.org/10.25126/jtiik.201853640.

Andriawan, A., \& Suparman, M. P. (2015). Pengembangan Media Pembelajaran Berbasis Video Demonstrasi Pada Mata Pelajaran Praktik Batu Kelas XI Jurusan Teknik Konstruksi Batu Beton Di SMKN 2 Pengasih. E-Journal Pend. Teknik Sipil Dan Perencanaan, 3(3), 45-47.

Arissusila, I. W. (2021). Degradasi Penggunaan Bahasa Bali di Kota Denpasar. VIDYA WERTTA: Media Komunikasi Universitas Hindu Indonesia, 4(1), 1-15. https://ejournal.unhi.ac.id/index.php/vidyawertta/article/view/1702.

Astuti, A. D., \& Prestiadi, D. (2020). Efektivitas penggunaan media belajar dengan sistem daring ditengah pandemi Covid-19. Prosiding Web-Seminar Nasional (Volume 20), $129-135$.

Banindro, B. S. (2019). Pengembangan Techno Virtual Berbasis Website sebagai Media Pembelajaran Rekayasa Visual Blender 3D bagi Mahasiswa Desain Produk. ANDHARUPA: Jurnal Desain Komunikasi Visual \& Multimedia, 5(01), 102-114. https://doi.org/10.33633/andharupa.v5i01.1965.

Dwiqi, G. C. S., Sudatha, I. G. W., \& Sukmana, A. I. W. I. Y. (2020). Pengembangan Multimedia Pembelajaran Interaktif Mata Pelajaran IPA Untuk Siswa SD Kelas V. Jurnal Edutech Undiksha, 8(2), 33. https://doi.org/10.23887/jeu.v8i2.28934.

Faisal, E. El, \& Sulkipani, S. (2016). Pengembangan bahan ajar berbasis muatan lokal pada mata kuliah Pendidikan Kewarganegaraan. Jurnal Civics: Media Kajian Kewarganegaraan, 13(2), 113-126. https://doi.org/10.21831/civics.v13i2.12721.

Hakim, A. R., \& Windayana, H. (2016a). Pengaruh Penggunaan Multimedia Interaktif Dalam Pembelajaran Matematika Untuk Meningkatkan Hasil Belajar Siswa SD. EduHumaniora | Jurnal Pendidikan Dasar Kampus Cibiru, 4(2). https://doi.org/10.17509/eh.v4i2.2827.

Hakim, A. R., \& Windayana, H. (2016b). Pengaruh penggunaan multimedia interaktif meningkatkan hasil belajar siswa SD. EduHumaniora | Jurnal Pendidikan Dasar Kampus Cibiru, 4(2), 1-13.

Handarini, O. I., \& Wulandari, S. S. (2020). Pembelajaran Daring Sebagai Upaya Study From Home (SFH) Selama Pandemi Covid 19. Jurnal Pendidikan Administrasi Perkantoran (JPAP), 8(3), 465-503. https://journal.unesa.ac.id/index.php/jpap.

Harjono, A., Gunawan, \& Sutrio. (2015). Multimedia Interaktif dalam Pembelajaran Konsep Listrik Bagi Calon Guru. Jurnal Pendidikan Fisika Dan Teknologi, 1(1), 9-14.

Jannah, M. ., \& Wiyatmo, Y. (2018). Pengembangan Media Pembelajaran Permainan Ludo untuk Meningkatkan Penguasaan Materi dan Minat Belajar Fisika Peserta Didik SMA. Jurnal Pendidikan Fisika, 7(2), 240-248. 
Kharisma, G. I., \& Arvianto, F. (2019). Pengembangan aplikasi android berbentuk education games berbasis budaya lokal untuk keterampilan membaca permulaan bagi siswa kelas 1 SD/MI. Premiere Educandum : Jurnal Pendidikan Dasar Dan Pembelajaran, 9(2), 203. https://doi.org/10.25273/pe.v9i2.5234.

Li, Q., Li, Z., \& Han, J. (2021). A hybrid learning pedagogy for surmounting the challenges of the COVID-19 pandemic in the performing arts education. Education and Information Technologies, 26(6), 7635-7655. https://doi.org/10.1007/s10639-02110612-1.

Loris, H. (2017). Pengembangan Multimedia Interaktif Pembelajaran Bahasa Mandarin. Jurnal Teknologi Informasi \& Komunikasi Dalam Pendidikan, 4(2). https://doi.org/10.24114/jtikp.v4i2.8762.

Lukman, A., Hayati, D. K., \& Hakim, N. (2019). Pengembangan Video Animasi Berbasis Kearifan Lokal pada Pembelajaran IPA Kelas V di Sekolah Dasar. Elementary: Jurnal Ilmiah Pendidikan Dasar, 5(2), 153. https://doi.org/10.32332/elementary.v5i2.1750.

Malyana, A. (2020). Pelaksanaan Pembelajaran Daring dan Luring dengan Metode Bimbingan Berkelanjutan pada Guru Sekolah Dasar di Teluk Betung Utara Bandar Lampung. Pedagogia: Jurnal Ilmiah Pendidikan Dasar Indonesia, 2(1), 67-76. https://doi.org/10.52217/pedagogia.v2i1.640.

Megawanti, P., Megawati, E., \& Nurkhafifah, S. (2020). Persepsi Peserta Didik terhadap PJJ pada Masa Pandemi COVID-19. Jurnal Ilmiah Pendidikan, 7(2), 75-82. https://doi.org/http://dx.doi.org/10.30998/fjik.v7i2.6411.

Nopriyanti, N., \& Sudira, P. (2015). Pengembangan multimedia pembelajaran interaktif kompetensi dasar pemasangan sistem penerangan dan wiring kelistrikan di SMK. Jurnal Pendidikan Vokasi, 5(2). https://doi.org/10.21831/jpv.v5i2.6416.

O’Byrne, W. I., \& Pytash, K. E. (2015). Hybrid and blended learning: Modifying pedagogy across path, pace, time, and place. Journal of Adolescent \& Adult Literacy, 59(2), 137-140. https://doi.org/10.1002/jaal.463.

Parvin, R. H., \& Salam, S. F. (2018). The Effectiveness of Using Technology in English Language Classrooms in Government Primary Schools in Bangladesh. FIRE: Forum for International Research in Education, 2(1). https://doi.org/10.18275/fire201502011049.

Patandung, Y. (2017). Pengaruh model discovery learning terhadap peningkatan motivasi belajar IPA Siswa. Journal of Educational Science and Technology (EST), 3(1), 9. https://doi.org/10.26858/est.v3i1.3508.

Prawiyogi, A. G., Purwanugraha, A., Fakhry, G., \& Firmansyah, M. (2020). Efektifitas Pembelajaran Jarak Jauh Terhadap Pembelajaran Siswa di SDIT Cendekia Purwakarta. Jurnal Pendidikan Dasar, 11(01), 94-101.

Purwanti, E., \& Krisnadi, I. (2020). Implementasi Sistem Perkuliahan Daring Berbasis ICT Dalam Masa Pandemi Wabah Covid -19. Pascasarjana Program Magister Teknik Elektro Universitas Mercu Buana.

Rahardjanto, A., Husamah, \& Fauzi, A. (2019). Hybrid-PjBL: Learning outcomes, creative thinking skills, and learning motivation of pre-service teacher. International Journal of Instruction, 12(2), 179-192. https://doi.org/10.29333/iji.2019.12212a.

Rahmadianto, S. A., \& Melany. (2018). Perancangan Multimedia Interaktif Pengenalan DKV Ma Chung sebagai Upaya Meningkatkan Brand Equity. ANDHARUPA: Jurnal Desain Komunikasi Visual \& Multimedia, 4(02), 130-142. https://doi.org/10.33633/andharupa.v4i02.1623.

Sahronih, S., Purwanto, A., \& Sumantri, M. S. (2019). The effect of interactive learning media on students' science learning outcomes. Proceedings of the 2019 7th 
International Conference on Information and Education Technology, 20-24. https://doi.org/10.1145/3323771.3323797.

Saichaie, K. (2020). Blended, Flipped, and Hybrid Learning: Definitions, Developments, and Directions. New Directions for Teaching and Learning, 2020(164), 95-104. https://doi.org/10.1002/t1.20428.

Saidah, K., \& Damariswara, R. (2019). Pengembangan Bahan Ajar Materi Dongeng Berbasis Kearifan Lokal Jawa Timur Bagi Siswa Kelas III SD. Premiere Educandum : Jurnal Pendidikan Dasar Dan Pembelajaran, 9(1), 73-81. https://doi.org/10.25273/pe.v9i1.4320.

Shen, C. wen, \& Ho, J. tsung. (2020). Technology-enhanced learning in higher education: A bibliometric analysis with latent semantic approach. Computers in Human Behavior. https://doi.org/10.1016/j.chb.2019.106177.

Sugiyono. (2014). Metode Penelitian Pendidikan Pendekatan Kuantitatif, Kualitatif, dan $R \& D$. Alfabeta.

Suryana, A. (2017). Pengembangan media audio visual menulis teks hasil observasi siswa kelas vii smp n 1 indralaya. Jurnal Pendidikan Bahasa Dan Sastra Indonesia Universitas Sriwijaya, 1-31.

Susilo, A., Rumende, C. M., Pitoyo, C. W., Santoso, W. D., Yulianti, M., Herikurniawan, H., Sinto, R., Singh, G., Nainggolan, L., Nelwan, E. J., Chen, L. K., Widhani, A., Wijaya, E., Wicaksana, B., Maksum, M., Annisa, F., Jasirwan, C. O. M., \& Yunihastuti, E. (2020). Coronavirus Disease 2019: Tinjauan Literatur Terkini. Jurnal Penyakit Dalam Indonesia, 7(1), 45. https://doi.org/10.7454/jpdi.v7i1.415.

Suwardani, N. P. (2015). Pewarisan nilai-nilai kearifan lokal untuk memproteksi masyarakat Bali dari dampak negatif globalisasi. Jurnal Kajian Bali, 5(2), 247-264. https://ojs.unud.ac.id/index.php/kajianbali/article/download/16775/11048.

Suweta, I. M. (2020). Adaptasi Bahasa Asing Dalam Bahasa Bali. Subasita: Jurnal Sastra Agama Dan Pendidikan Bahasa Bali, 1(1), 1-10. https://stahnmpukuturan.ac.id/jurnal/index.php/subasita/article/view/598/0.

Tegeh, I. M., \& Jampel, I. N. (2017). Metode Penelitian Pengembangan. Universitas Pendidikan Ganesha.

Triana, N. N., \& Retnosary, R. (2020). Pengembangan Model Pemasaran Batik Karawang sebagai Produk Unggulan Daerah. Jurnal Inovasi Dan Pengelolaan Laboratorium, 2(1), 21-27.

Widyatmojo, G., \& Muhtadi, A. (2017). Pengembangan multimedia pembelajaran interaktif berbentuk game untuk menstimulasi aspek kognitif dan bahasa. Jurnal Inovasi Teknologi Pendidikan, 4(1), 38-49. https://doi.org/10.21831/jitp.v4i1.10194.

Wuarlela, M. (2020). Variasi Metode Dan Media Pembelajaran Daring Untuk Mengakomodasi Modalitas Belajar. ARBITRER: Jurnal Pendidikan Bahasa Dan Sastra Indonesia, 2(2), 261-272. https://doi.org/10.30598/arbitrervol2no2hlm261-272

Yusantika, F. D., Suyitno, I., \& Furaidah, F. (2018). Pengaruh Media Audio dan Audio Visual terhadap Kemampuan Menyimak Siswa Kelas IV. Jurnal Pendidikan: Teori, Penelitian, Dan Pengembangan, 3(2), 251-258. https://doi.org/http://dx.doi.org/10.17977/jptpp.v3i2.10544.

Yuzulia, I. (2021). The Challenges Of Online Learning During Pandemic : Students ' V oice. Jurnal Bahasa Dan Sastra, 13(1), 8-12. https://doi.org/10.31294/w.v13i1.9759. 